\title{
WestVirginiaUniversity
}

THE RESEARCH REPOSITORY @ WVU

Graduate Theses, Dissertations, and Problem Reports

1999

\section{Building a bisque kiln}

David Buchanan

West Virginia University

Follow this and additional works at: https://researchrepository.wvu.edu/etd

\section{Recommended Citation}

Buchanan, David, "Building a bisque kiln" (1999). Graduate Theses, Dissertations, and Problem Reports. 1887.

https://researchrepository.wvu.edu/etd/1887

This Thesis is protected by copyright and/or related rights. It has been brought to you by the The Research Repository @ WVU with permission from the rights-holder(s). You are free to use this Thesis in any way that is permitted by the copyright and related rights legislation that applies to your use. For other uses you must obtain permission from the rights-holder(s) directly, unless additional rights are indicated by a Creative Commons license in the record and/ or on the work itself. This Thesis has been accepted for inclusion in WVU Graduate Theses, Dissertations, and Problem Reports collection by an authorized administrator of The Research Repository @ WVU. For more information, please contact researchrepository@mail.wvu.edu. 


\title{
Building A Bisque Kiln
}

\author{
David Buchanan \\ Master's Thesis submitted to the College of Creative Arts at \\ West Virginia University \\ in partial fulfillment of the requirements

Master of Fine Arts
in
Art \\ Robert Anderson, Chair \\ Alison Helm \\ Kristina Olson \\ Christopher Hocking
}

\begin{abstract}
Morgantown, West Virginia
1999
\end{abstract}

Keywords: Bisque Kiln, Kiln, Electric Kiln, Ceramics 


\begin{abstract}
The electric kiln in the studio of the ceramic artist is one of many important and significant pieces of equipment. It is the goal of this paper to provide a guide to anyone who needs to repair, rebuild, or build from scratch an entire kiln. These step-by-step instructions for building a kiln from bought materials will provide the information necessary to fix minor and major kiln rebuilding projects .

This manual/ guide is the result of researching kilns, both in terms of doing extensive reading on the subject and gaining real experience. Found in the way of rebuilding/rebricking heavily abused kilns, rewiring, and setting up kilns for the first time with the hard wiring from the electrical entrance to the receptacle. Doing this hands -on research allowed me to find out how the kiln works, how it's assembled and to learn what procedures it's designed to execute.
\end{abstract}




\section{TABLE OF CONTENTS}

Title Page $\quad$ i

Abstract

Table of Contents iii

Introduction 1

Personal Statement 2

Discussing and Deciding Kiln Size and Shape 3

Amperage and Element Requirements 4

Designing and Assembling the Rings of the Kiln 5

$\begin{array}{lr}\text { Elements of Elements } & 8\end{array}$

$\begin{array}{ll}\text { Winding Suggestions } & 10\end{array}$

$\begin{array}{ll}\text { Installing Elements } & 11\end{array}$

$\begin{array}{lr}\text { Kiln Floor } & 12\end{array}$

$\begin{array}{lr}\text { Kiln Lid Construction } & 14\end{array}$

Wiring the Electric Kiln 16

$\begin{array}{ll}\text { Conclusion } & 17\end{array}$

$\begin{array}{ll}\text { Notes } & 18\end{array}$

$\begin{array}{ll}\text { Bibliography } & 19\end{array}$

$\begin{array}{ll}\text { Illustrations } & 20\end{array}$ 


\section{INTRODUCTION}

The electric kiln which was developed in the twentieth century was first developed for industry and later worked its way into the studio of the ceramic artist as one of many important and significant pieces of equipment for control and repeated results. Unfortunately, many know little about the construction and its workings. A dysfunctional kiln can be detrimental to the production and progression of one's work. It is the goal of this paper to provide a guide to anyone who needs to repair, rebuild, or build from scratch an entire kiln. These step-bystep instructions for building a kiln from bought materials will provide the information necessary to fix minor and major kiln rebuilding projects.

This manual/ guide is the result of researching kilns, both in terms of doing extensive reading on the subject and gaining real experience. Found in the way of rebuilding/rebricking heavily abused kilns, rewiring, and setting up kilns for the first time with the hard wiring from the electrical entrance to the receptacle. Doing this hands -on research allowed me to find out how the kiln works, how it's assembled and to learn what procedures it's designed to execute.

As a developing potter, knowing the skills of repairing or building a kiln will be significant for preparing and testing my personal work. The bisque kiln is just thought of as a tool, but it is very important for my work and many other individuals. Bisquing pots helps with increasing the numbers of production pots. Without the bisque kiln, single firing work is necessary and this can result in lost pots from thermal shock.

Another results of bisqued pots are a porous pot that gives my work the ability to be heavily sprayed with glazes and oxides, a task that if performed on green ware pots, can result in cracking. Also used by potters and institutions, the bisque kiln also has the capability to be use for a low fire glaze kiln, for majolica low fire glazing and oxide decoration. I feel the bisque kiln as a tool in the studio is an important part of my work. 
My work to date has been influenced by a multiple of things, work shops, pots in magazines, historical books, etc.. and the most, the love of building pleasing forms for others for some kind of function/ use. I believe that the influence of wanting to make pots for function is one of the most upstanding concepts. I'm definitely not the best at expressing anything that I feel emotional about, but it's simple and to the point. I also feel that the work should speak for it self, and at least be visually pleasing and something one can live with, much how I feel about work in the art world should resemble. 


\section{DISCUSSING AND DECIDING ON KILN SIZE AND SHAPE}

When thinking about designing an electric kiln there are particular features to think about: size, shape and amperage.

Size brings up two things to consider. One is dimension- an electric kiln is able to achieve any size imaginable with the restriction of a maxim distance of interior space of 30" in any one direction. A greater distance than this will result in a kiln with uneven heating and cold centers(1). The second thing to consider when sizing a kiln is simply, "will the kiln of chosen size fit in the chosen location with a minimum space of 12 "around the kiln?(2).

There are two common shapes and there are pros and cons to both. The round to oval kiln has the qualities of mobility of lighter sections. The construction of a round kiln also requires more time-consuming decisions on brick design to achieve the proper shape of a kiln. In the square design the assembly is quick and simple with the draw back of having a large heavy kiln that is difficult to move.

The final thing to consider is the amperage of the kiln. Kilns with a cubic foot measurement of approximately 4' run an amperage of 30 and a 9-cubic-foot kiln run up to 65 amps. Kilns running on 30 amps are not a problem in most households. The kilns pulling 65 and even 70 amps in older homes with60,80and even 100 amp electric entrances can result in the trip of the main breaker with other appliances in use.

A final suggestion for first time constructors of a kiln is to find an existing one that meets your size, shape and amperes requirements then copy it. This will help with calculating dimensions and acquiring the proper parts.

The kiln assembled in this manual is very similar to the Skutt $714+\mathrm{BR}$ with size 24" across and 27" deep. 


\section{AMPERAGE AND ELEMENT REQUIREMENTS}

The amperage and element requirements are determined by the cubic feet of the kiln and using the chart from figure A(3). After deciding on a particular size kiln, look at the cubic feet on the chart and knowing your incoming household voltage determine the amps and amount of elements needed. Knowing the amps is important for knowledge of the breaker that's needed for your electrical box. The number of elements must be known to get to proper temperature. 
When designing with standard 3"x41/2"x9" brick the builder must determine the angle which will be cut to the brick to acquire the round kiln. In the Skutt $714+\mathrm{BR}$, one layer of one ring will take nine bricks. To find the angle the number 360 , the total degrees of a circle, is simply divided by nine, and ending up with 40 , the angle used to get the size circle desired. When using 12 bricks divide 360 by 12 , the angle becomes 30. This also, when the bricks are laid out after the angles are cut, measures 30 inches across the maximum width of a kiln where one does not want to get uneven heating.

Materials:

Insulating fire brick approximately 3 boxes of 25 with a rating of

2300 Fahrenheit
brick size: $3 " \times 4 " x 9 "$
Aluminum flashing
$10 " x 50$ ' roll
Aluminum rivets
One pack of 100
Scrap plywood
3/4" thick
5/8" screws
approximately 30
Duct tape
One roll

Tools:

All thread

3/8" thickness

two lengths of $11 / 2^{\prime}$ to $2^{\prime}$ 


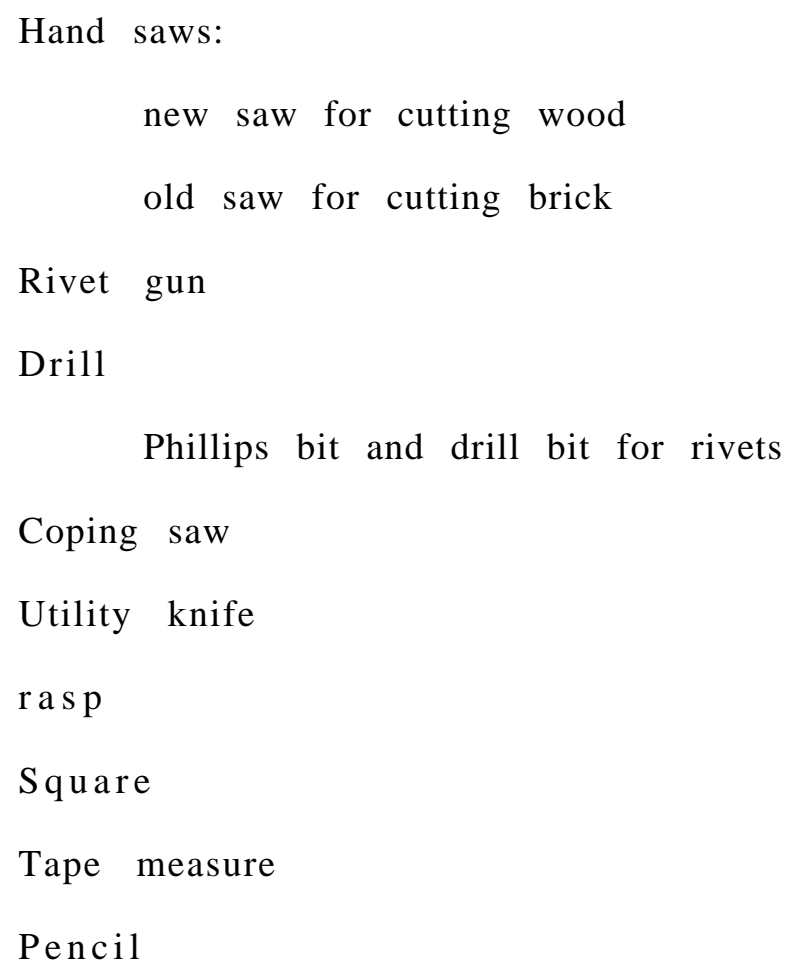

Construction of the three rings is done in two divisions which is one, the construction of the brick and two the final assembly of each of the rings.

The forming of the brick is done by the use of a jig(4) made of ply- wood and the $15 / 8 "$ screws. The jig(figure 1a) is built to allow the brick to drop in and the slots on both sides of the jig are made by using a coping saw. Duct tape on the ends of a piece of the $3 / 8$ "all thread can be used as a rasping tool to create the groove that allows the element to lie within (figure 1b). Grooves that are routed at a diameter of1/2" will accommodate elements wound on 1/4"and3/8" rods.

The final part of forming of the brick is getting the angle. Using a bevel square, the angle is transferred to the back of the jig(figure 1c). Next the angle on the jig is cut with a handsaw and brick. The brick is cut using another older disposable handsaw (figure 1d).

Part two of the ring construction is assembling the brick and the aluminum jacket. Start with the fabrication of the aluminum jacket.(Some prefer the more durable stainless steel jackets similar to the jackets found and made by kiln 
industries. This material requires special equipment for fabrication.) The outer distance around the kiln is measured following the assembly of the pre-cut brick in the final shape of the kiln (to resolve the final shape of the kiln a rasp is used to ensure that the bricks have a tight fit). The distance is found and 12 more inches are added. The extra 12 inches are divided into two six- inch lengths that are folded over each end( figure 2a) for strength of the attachment of the pipe clamps.

Cutting of the aluminum flashing is done by scoring the metal several times and bending to snap it off. Folding the jacket is done by using two pieces of wood with the aluminum sandwiched in between and folded over(figure 2b). The attachment of the pipe clamp begins with cutting the clamp approximately two inches in from the screw side ending up with two parts that are riveted at opposite ends of the aluminum jacket. This is done in sets of three done on each jacket (figure 2c). The final step is to attach the jacket which is simply done by wrapping it around two layers of brick in the shape of the ring and screwing together(figure $2 d)$. 


\section{Elements of elements}

Determining the boundaries of the elements within the electric kiln is considered the most difficult aspect of construction. The two things to consider are the make of the wire and how the wire needs to be wound. Determining wire type is decided by the temperature that the kiln is required to achieve and the typical ceramic artist will require either low-fire wire which only needs nichrome wire that is suitable to $1000^{\prime} \mathrm{c}$ (1832'f- cone 06$)$, or high-fire wire for up to $1305^{\prime} \mathrm{c}(2381$ cone10) which require a kanthal wire(5). There are the rare occasions that some individuals, but mostly industry, require to fire higher than cone 10 within the electric kiln and special elements are required. These elements/rods are made of silicon carbide and they reach up to cone $30(6)$.

Winding elements/coils is best with wire of a gage between 16 and 13. Wire thinner than 16 gage becomes too thin for high fire and burn outs of coils are common and thicker than 13 gage becomes difficult to wind without machinery(7). When winding the elements a few rules must be followed to get the final dimensions of the element correct. The element, after wound and stretched should, theoretically speaking, end upsix to eight times higher then the thickness of the wire and 2.25 times the thickness from the top point to top point of each loop or 1-1.25 between the inside loops of the element( figure 3a). When deciding on a winding rod, 16-15 gage wire a1/4"rod is and for 14-13 a 3/8"rod is satisfactory to attempt the theoretical six to eight $\operatorname{ratio}(8)$.

\section{Winding Elements}

When winding for elements a few materials are required.

Materials:

scrape plywood:

$1 / 2 "-3 / 4 "$

Lumber:

scrape $2 \times 4$ or $4 \times 4$ 
1-5/8 screws:

approximately 30

Wire:

3 pounds(381') of kanthal wire, 15 gage

50 ' of cheep steel 15 gage wire

4' steel rod,1/4"

$\underline{\text { Tools }}$

Drill

with 1/4" drill bit and Phillips screw driver bit

Hand saw

Wire cutters

Pliers

Tape Measure

pencil

Starting off with the much feared task of winding elements, a jig is made(figure $4 \mathrm{a} \& 4 \mathrm{~b})(9)$. Set up the jig in a spacious area. The steel wire is fed though the bottom of the jig for a practice wind. Taking the wire and the 1/4" steel rod, both are tightened into the drill chuck. Next a $4 "$ lead is stretched with the winding following by simply starting the drill. To get the proper length of the element the inside circumference of the kiln is measured(58.25") and that number is cut in half(29.25). Winding the coil tight at 29.25 and stretching to $581 / 2$ gave the needed approximate distance from one top of a loop to the next, which is 2-2.25, the thickness of the element(1-1.5 the thickness of the between the insides of the element)(10). After a few trial winds the kanthal wire is wound. 


\section{Winding Suggestions}

Start off winding slowly with a 4" lead until the desired length and ending with 4" lead. Removing the wire from the steel rod is done by loosening the chuck on the drill and only removing the wire. Next tighten the chuck onto the steel rod and put the drill into reverse while pushing the coil away from the drill with pliers. When stretching the element, have a helper hold close to the first wind with pliers and pull the other end, with pliers, to desired length. 


\section{Installing Elements}

\section{$\underline{\text { Tools and materials }}$}

Drill:

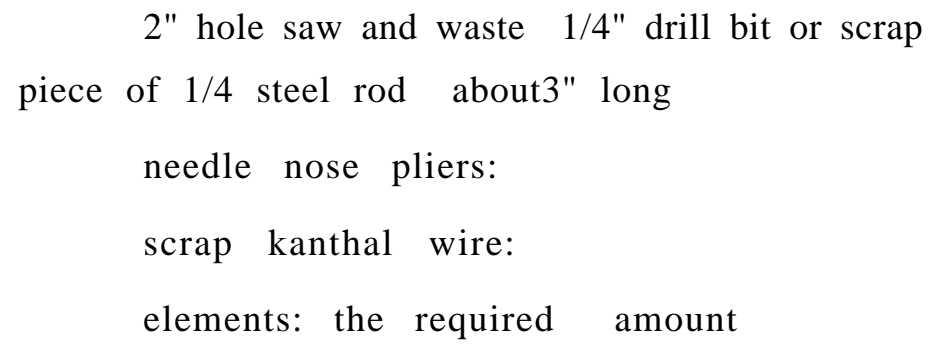

When installing the elements into the kiln there needs to be an area for the elements to come through the kiln walls for wiring. The openings are made by using a 2" holesaw and placed on the outside of the kiln with the center of the hole saw level with the element groove on the inside of the kiln. Next, using the waste drill bit, drill two holes 3/4" apart from the outside of the kiln to the inside element groove to allow leads of the element to protrude out(figure 5a). (Porcelain insulators are recommended for element leds to travel through the kiln wall). Place the element into the kiln by simply lying it into the groove and inserting leads into the two previously drilled holes. Elements that ended up shy of making the distance around should be removed and restretched for proper amount. Staples an inch long and 3/16" wide can be used to secure the elements. Three staples in every brick were found to be the most suitable. 


\section{KILN FLOOR}

The kiln being assembled, like all kilns requires a floor for the kiln to rest upon.

MATERIALS:

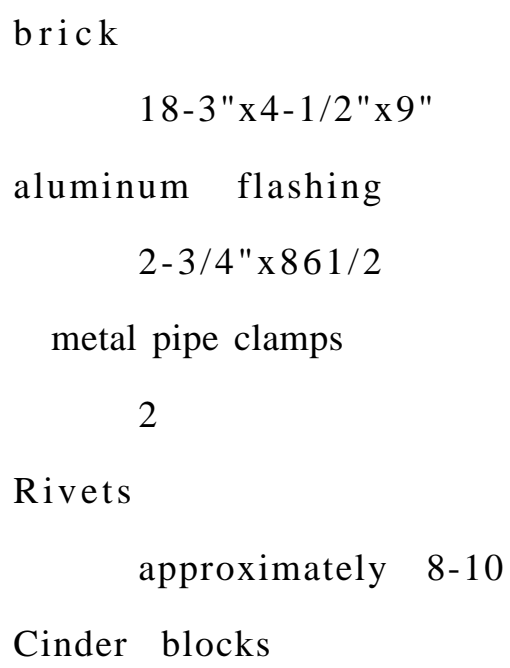

Tools

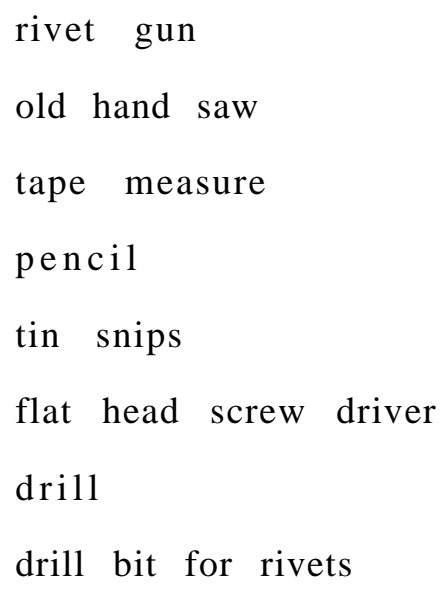




\section{small square}

The floor construction of the kiln is definitely the simplest part of the fabrication of the kiln. 18 bricks are laid flat and tight together with one ring of kiln on top. Take a pencil and trace the ring then remove. Following the removal of the ring the bricks are cut and then banded the same way as the kiln body rings(figure 6a). With six cinder blocks or another layer of insulation brick a stand is simply constructed and the kiln can be placed upon it for support of the base. 


\title{
KILN LID CONSTRUCTION
}

\section{MATERIALS}

\author{
Steel \\ $1 / 4 " 25 " x 25 "$ expanded steel \\ fiberfrax \\ scrape from refractory companies can given \\ or bought at low prices \\ kanthal wire \\ scrape wire from winding elements were \\ used \\ wire \\ 3/16" uncoated wire-15 feet \\ s hooks \\ approximately 6 \\ wire clamps \\ $3-4$ \\ pulleys \\ 2 \\ counter weight \\ the counter weight that was used for the \\ project was a small bucket with sand- \\ other suggestion are old window weights and \\ old barbell weights
}




\title{
TOOLS
}

\author{
wire cutters \\ needle nose pliers \\ utility knife
}

Like the base of the kiln the lid is another simple construction. Starting with the expanded steel, 2" of scrape fiberfrax is stapled with 2-1/2" staples upon it. This is done by pushing the staples though the fiber and twisting the staple on the other side (figure 7a). Finishing stapling of the fiber, the expended steel/ fiberfrax lid is turned over and the pig tails are sniped off. With the pulleys, 10' (The length of the wire depends on the distance the counter weight needs to be away from the kiln) of wire and 2 wire clamps the pulley system is assembled.

The pulleys are tied into ceiling joist approximately 4 feet apart. Next the wire is strung though the pulleys and wire clamps attach at each end with s- hooks affixed. The lid required 3-4 s hooks, with wire looped though them and a wire clamp holding it together to make one solid loop. This is to hang on to one end of the upper wire. A counter weight is next hooked on to the other end of the upper wire for the smooth floating lid (figure $7 \mathrm{~b}$ gives you the final lid assemble). 
As the plans for wiring the kiln are being resolved, the initial thought is to purchase the switches and to fabricate the remainder of the switch box. The switch boxes can be planed to be made from coffee cans and down to the element wire connectors, thought to be made of just a stainless steel nut and a bolt. As measurements are taken, the coffee cans are found to be to small, and the nuts and bolts are found to disconnect too easily ( The stainless steel nuts and bolts will work in cases of need, but is recommended to replace with the proper manufactured element connectors). The final decision, after weighing out one's time and energy, is found to buy a complete switch box kit. This includes everything from the switches, plug, wires, boxes, connectors and wire blocks. The switch box instructions for wiring of the entire box are available, which for many who are not familiar with basic wiring is essential. 


\section{CONCLUSION}

With the information given within this paper/ manual an individual should be capable in building and repairing the potter's electric kiln. When repairing the kiln, repairs shall be cheaper and faster for the continuation of production. 


\section{NOTES}

1 Frederick Olsen, The Kiln Book(Radnor,P.A.: Chilton Book Company), 224-225. and Daniel Rhodes Kiln Design, Construction and Operation(Radnor,P.A.: Chilton Book Company), 142.

2 Harry Fraser, Electric Kilns(New York,N.Y.: Watson-Guptill), 23.

3 Olsen, 242.

4 Bob Anderson, Interview, October 1997.

5 Robert Fournier, Illustrated Dictionary of Practical Pottery(New York,N.Y.: Chilton Book Company), 99-101.

6 M.Wikey, Calibrating and Calculating the Electric Kiln(SanJose,C.A.: Marshall Craft), 94-95.

$7 \quad$ Fournier, 101.

8 Ibid., 101.

9 Fournier, 100 and Wikey, 89-90.

10 Fournier, 101. 


\section{BIBLIOGRAPHY}

Anderson,Bob. Interview. _October,1997.

Fraser, Harry. Electric Kilns.New York, N.Y.: Watson-Guptill,1974.

Fournier,Robert. Illustrated Dictionary of Practical Pottery. New York, N.Y. Chilton Book Company, 1992.

Olsen,Frederick. The Kiln Book. Radnor, P.A.: Chilton Book Company,1983.

Rhodes,Daniel. Kilns Design, Construction, and Operation.Radnor, P.A: Chilton Book Company, 1968.

Wikey,M. Calibrating and Calculating The Electric Kiln.SanJose, C.A: Marshall Craft, 1974. 
FIGURE A

Table 8-6

Kilowatt Power Calculations

\begin{tabular}{|c|c|c|c|c|}
\hline $\begin{array}{l}\text { Vol ume } \\
\left(f t^{3}\right)\end{array}$ & Kilowatts $=$ & vdts & Amps & $\begin{array}{l}\text { El ements } \\
\text { Requir ed }\end{array}$ \\
\hline 1 & 1.800 & 120 & 15 & - \\
\hline \multirow[t]{3}{*}{2} & 4.600 & 230 & 20 & 3 \\
\hline & 5.500 & $220 / 240$ & & \\
\hline & 4.600 & $230 / 208$ & 20 (three-wire) & 3 \\
\hline \multirow[t]{3}{*}{3} & 5.290 & 230 & & \\
\hline & 5.060 & 230 & 22 & 4 \\
\hline & $5.76 c$ & 240 & 24 & 4 \\
\hline \multirow[t]{3}{*}{4} & 8.050 & 230 & 35 & - \\
\hline & 11.000 & $208 / 240$ & 26.6 (three-phase) & - \\
\hline & 10.800 & 240 & 45 & - \\
\hline \multirow[t]{3}{*}{5} & 14.400 & 2201240 & 60 & - \\
\hline & 8.850 & 230 & 38.5 & - \\
\hline & 7.800 & 230 & 34 & - \\
\hline 6 & 9.200 & 230 & 40 & 5 \\
\hline \multirow[t]{2}{*}{7} & 16.800 & $22 \mathrm{O} / 240$ & 70 & - \\
\hline & 11.250 & 230 & 47 & \\
\hline \multirow[t]{3}{*}{8} & 14.400 & $220 / 240$ & 60 & - \\
\hline & 10.350 & 230 & 45 & $\overline{5}$ \\
\hline & 9.200 & 230 & 40 & \\
\hline \multirow[t]{2}{*}{10} & 13.800 & 230 & 60 & 6 \\
\hline & 26.000 & 240 & 108 & - \\
\hline \multirow[t]{3}{*}{13} & 30.000 & $220 / 240$ & 125 & - \\
\hline & 24.000 & $220 / 240$ & 100 & - \\
\hline & 25.000 & $220 / 240$ & 75 & - \\
\hline 15 & 34.500 & 230 & 150 & 6 \\
\hline \multirow[t]{3}{*}{16} & 36.000 & $220 / 240$ & 150 & - \\
\hline & 30.000 & $220 / 240$ & 125 & - \\
\hline & 24.000 & 240 & 100 & 5 \\
\hline
\end{tabular}

almost all situations is enough to feed the kilns included in Table 8-6, except the three-phase kiln. However, it is advisable to have 200-amp service, which is only a small additional cost and will allow a studio or pottery enough amperage to operate.

\section{CALUATINGWFE ELEMENTS}

In order to calculate elements for a kiln, one needs to know:

1. kiln temperature

2. amount of voltage available kiln capacity (volume)

4. number of circuits 


\section{FIGURE 1A}

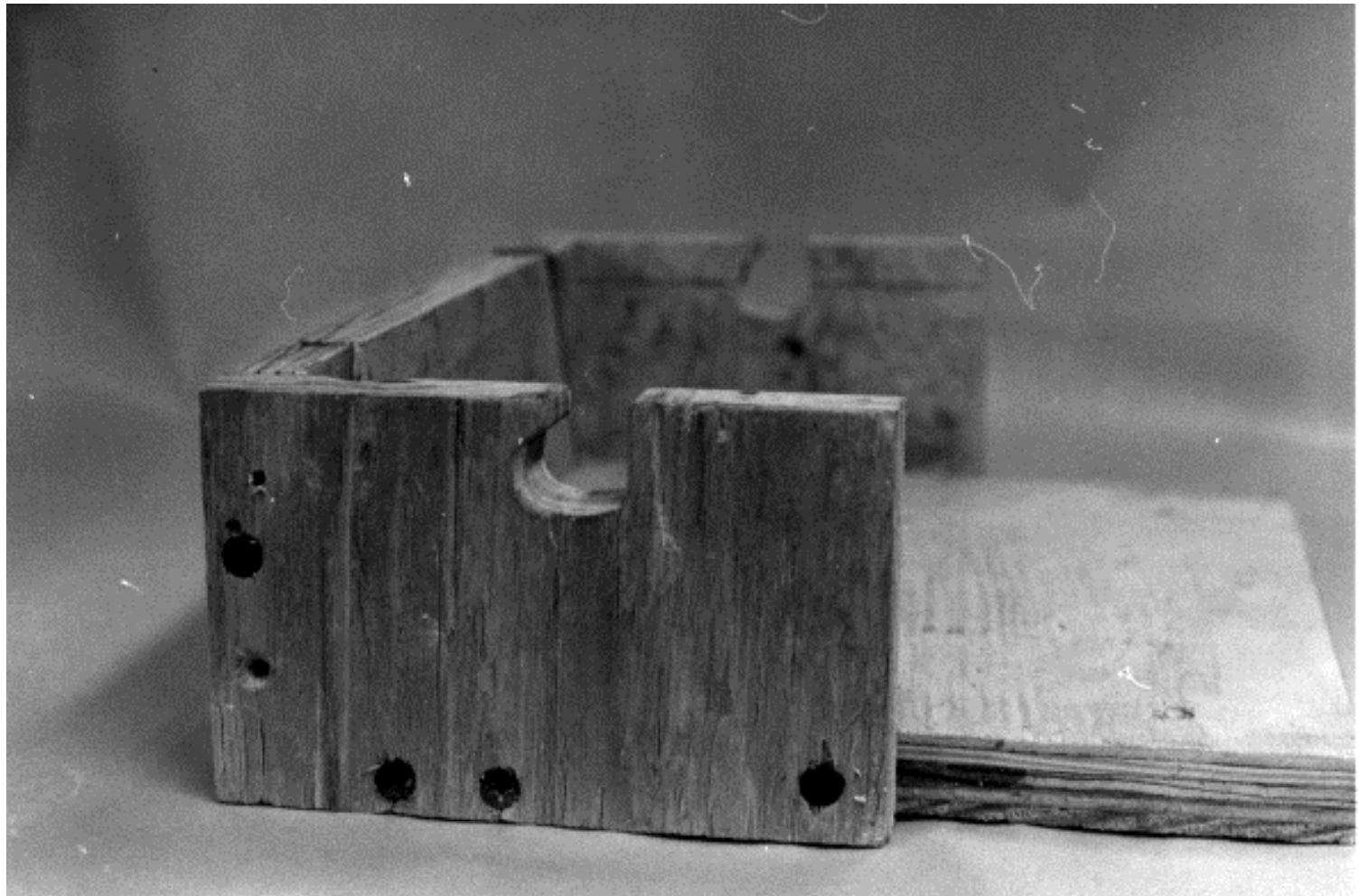

\section{FIGURE 1B}

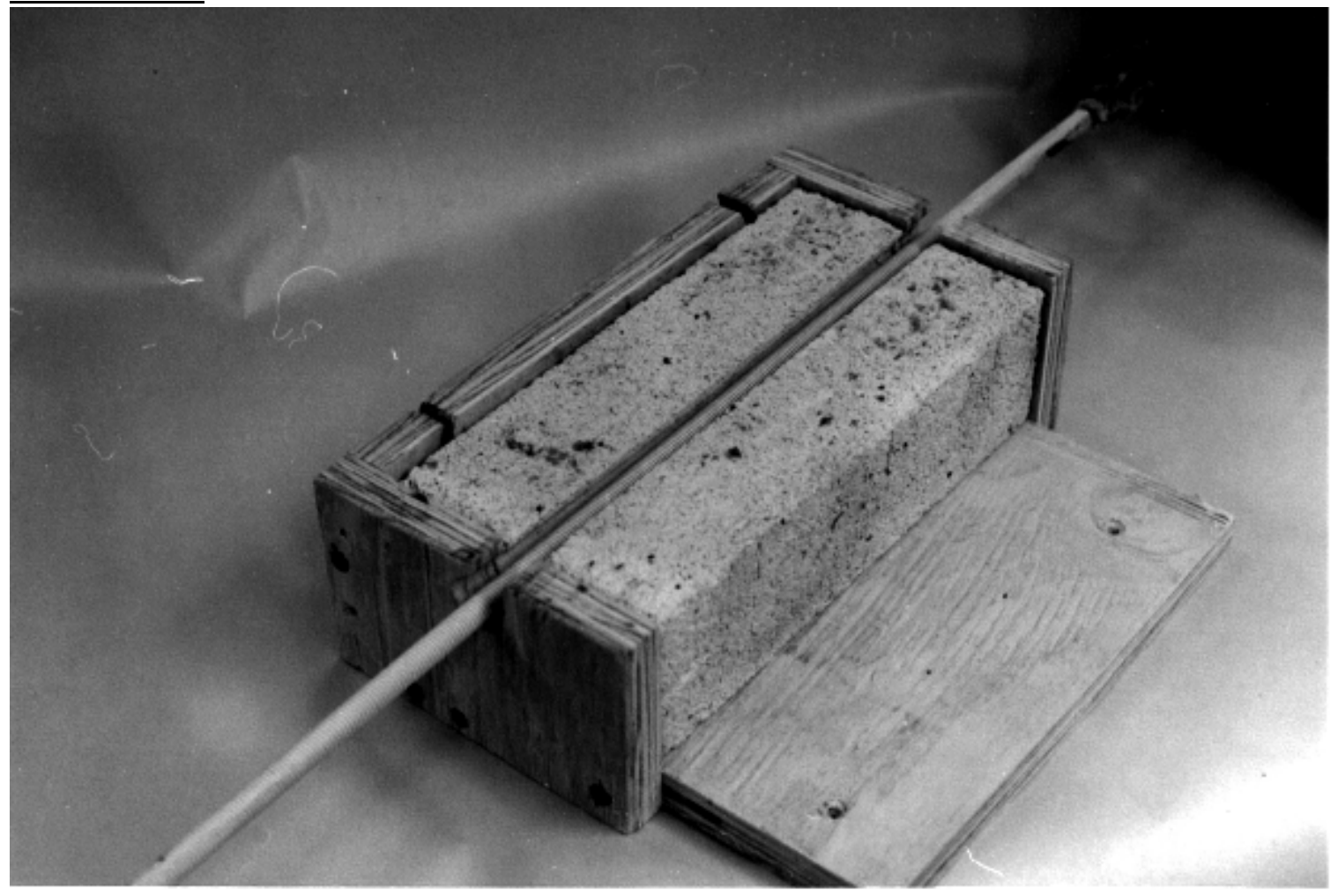




\section{FIGURE 1C}

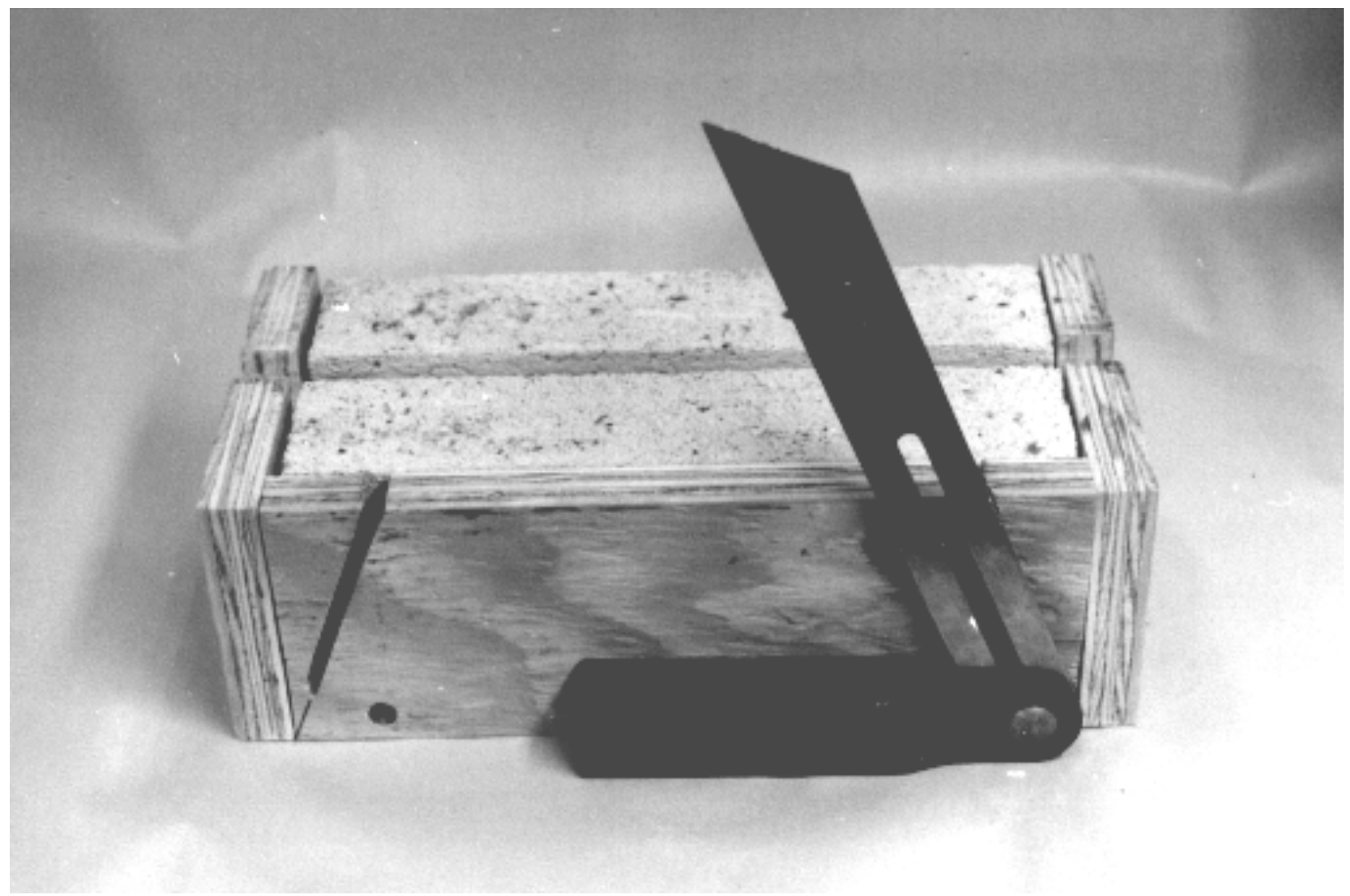

\section{FIRGUE 1D}

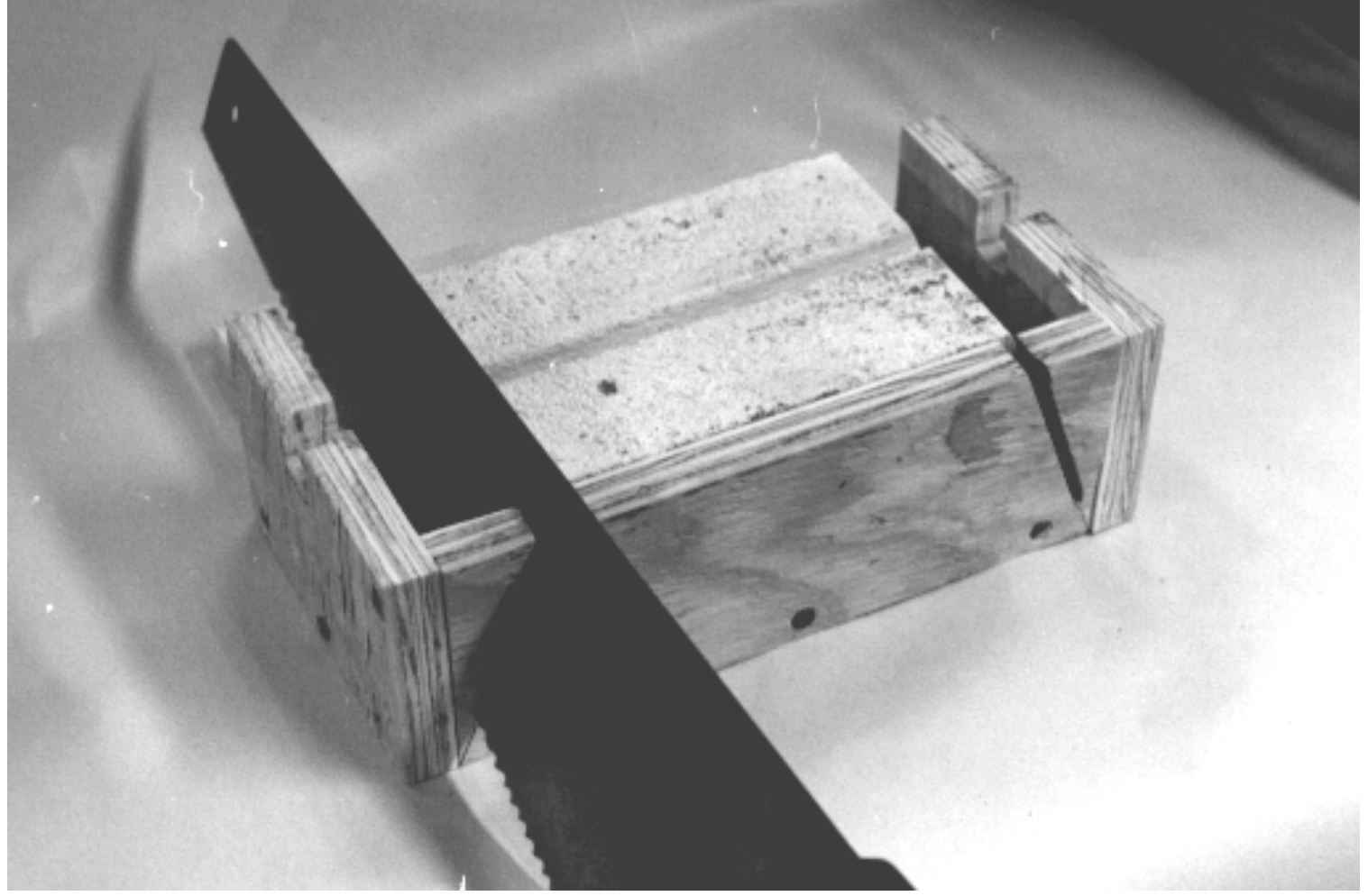




$$
2
$$




\section{FIGURE 2C}

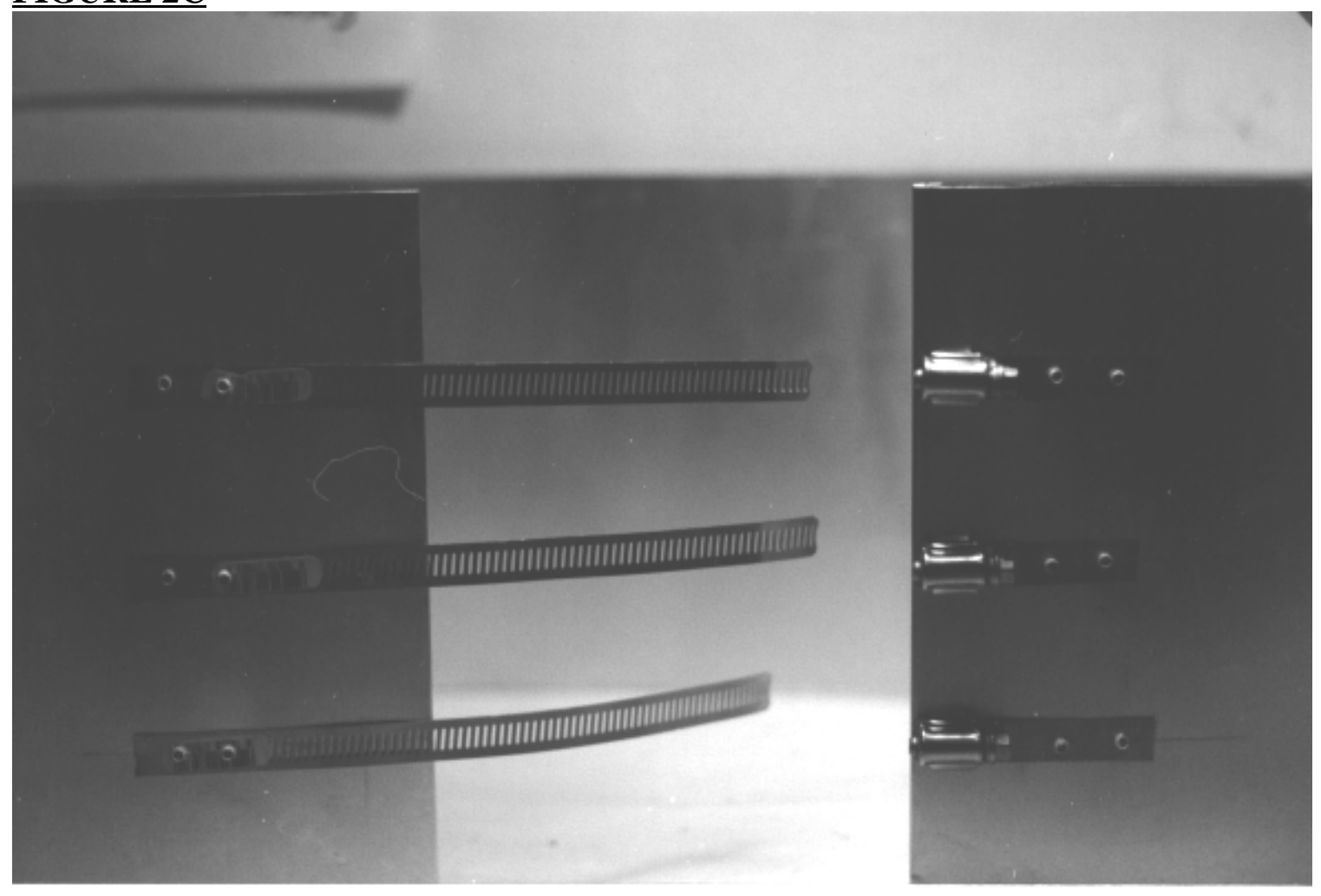

\section{FIGURE 2D}

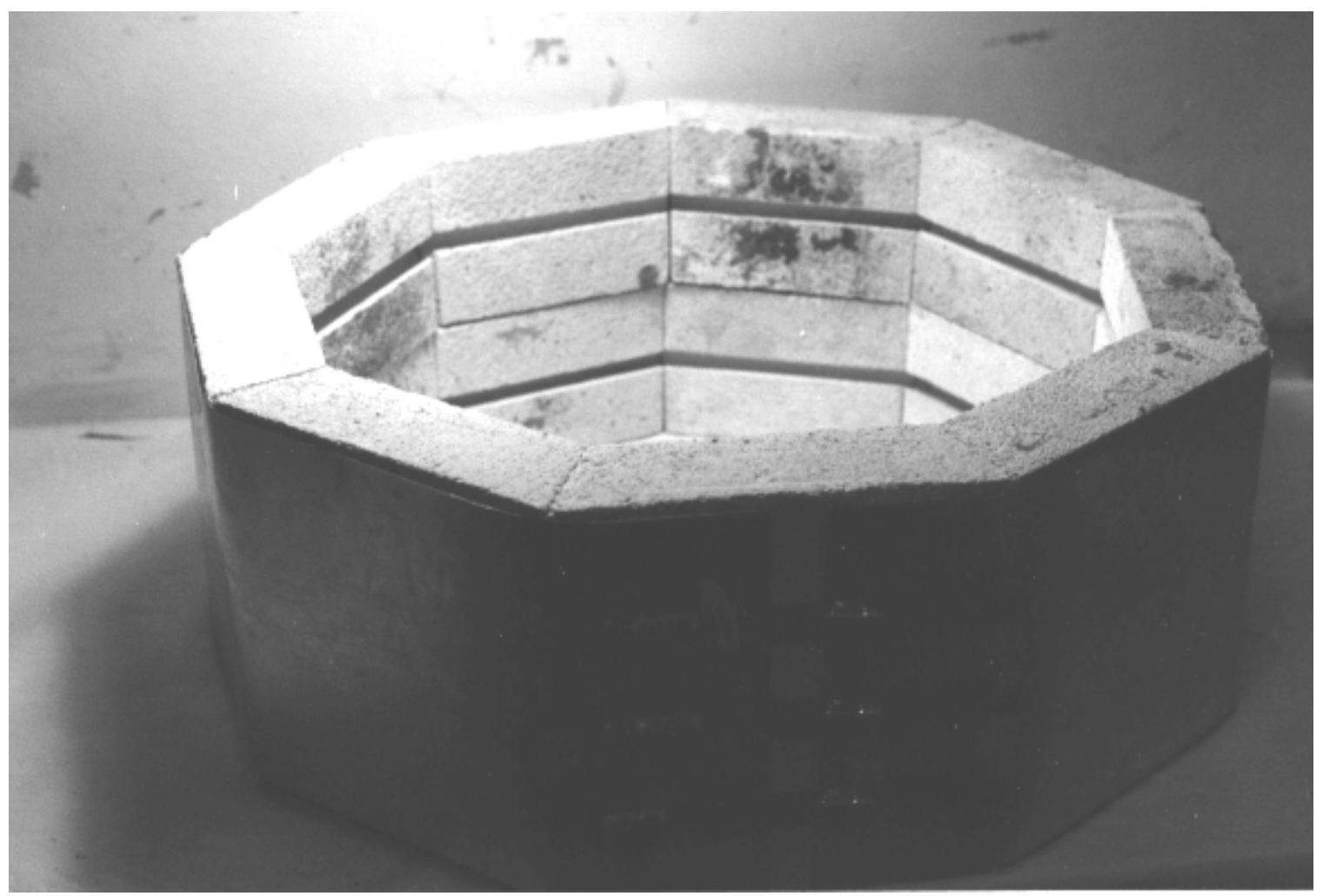


FIGURE 3A

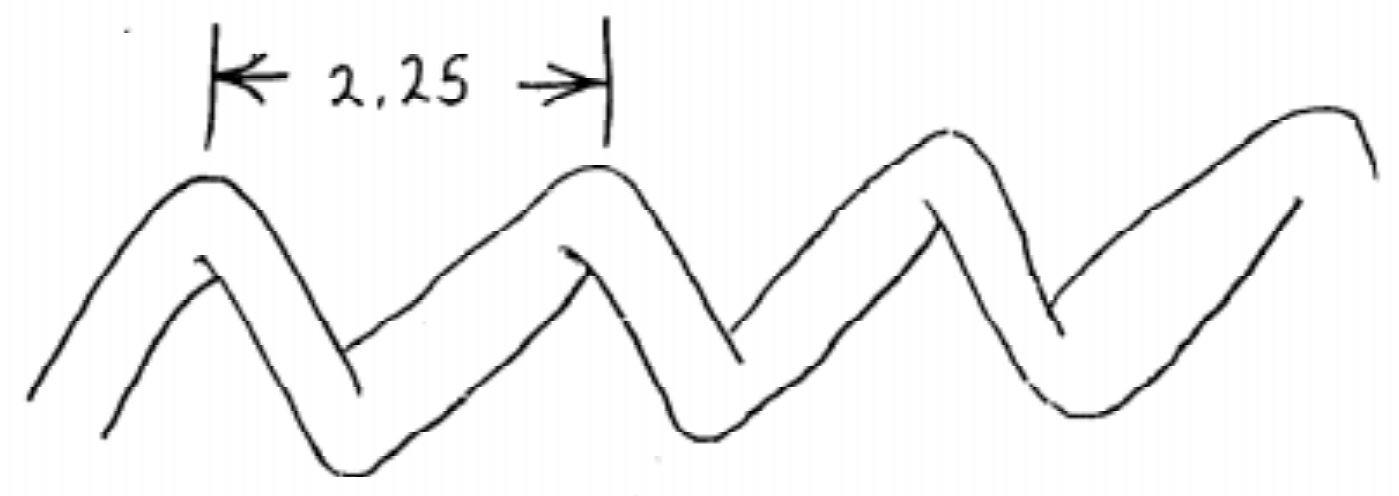

\section{FIGURE 4A}

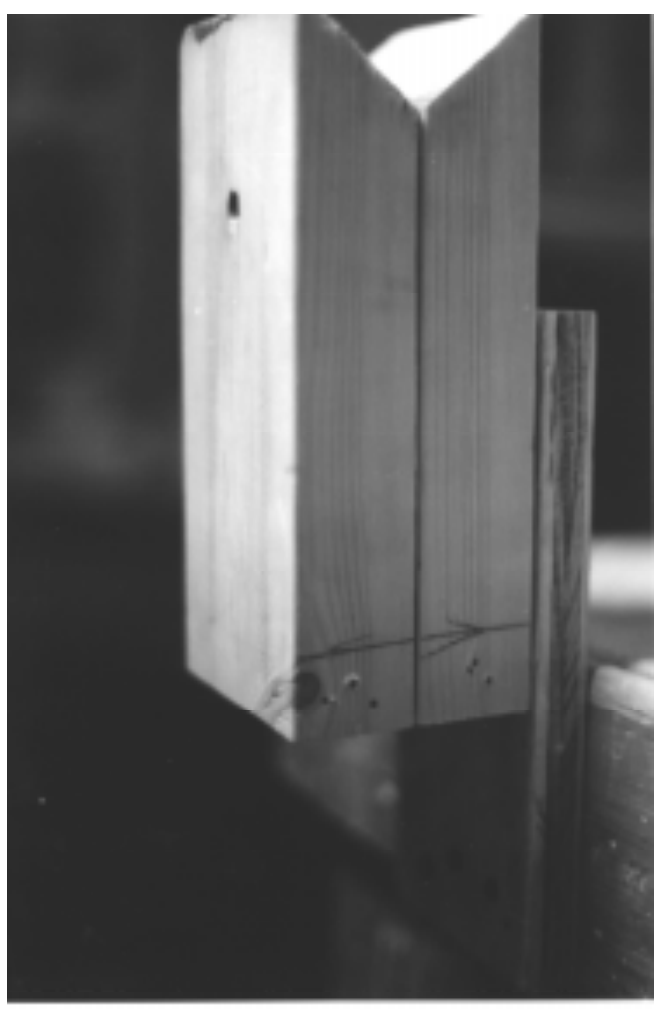




\section{FIGURE 4B}

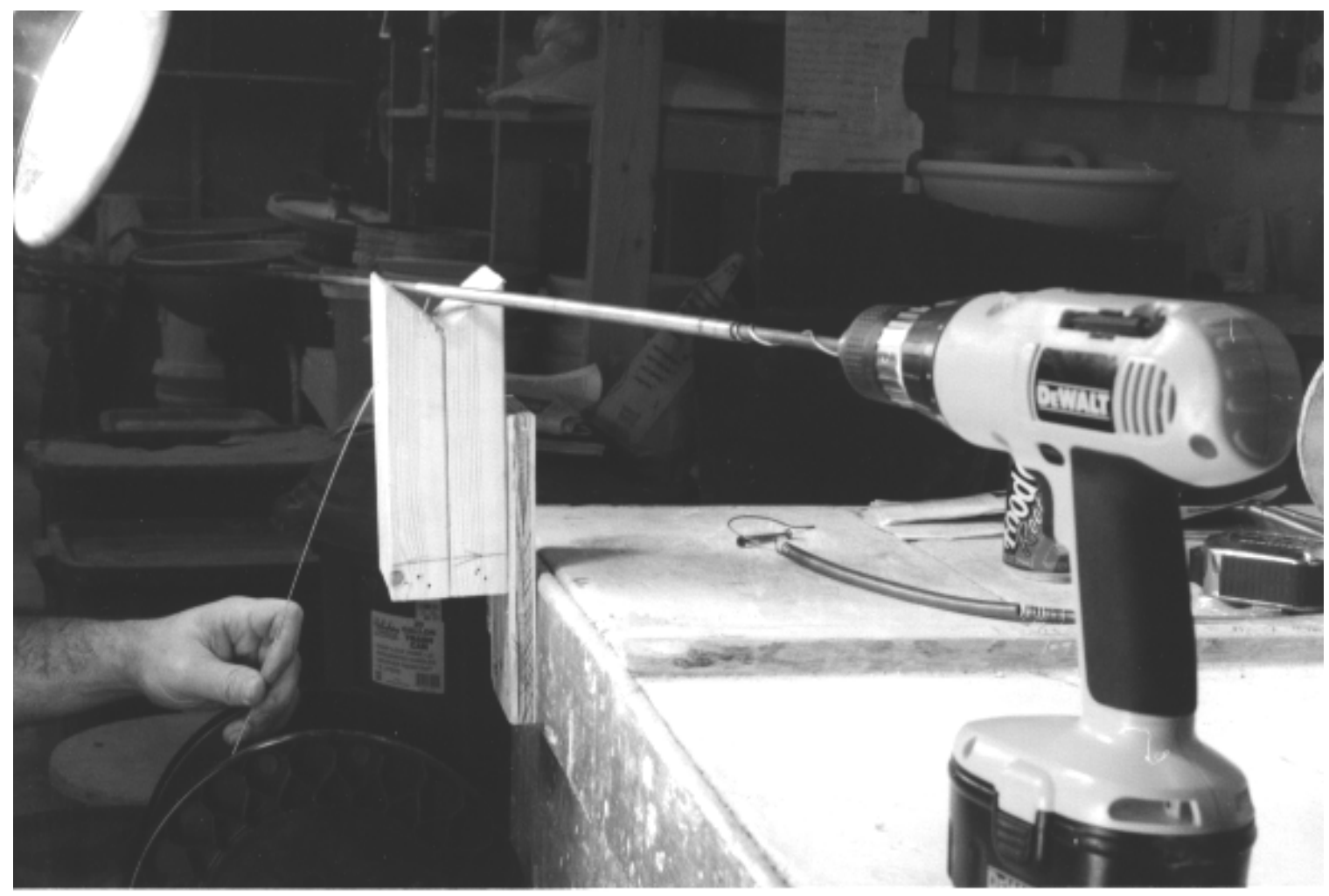

\section{FIGURE 5A}

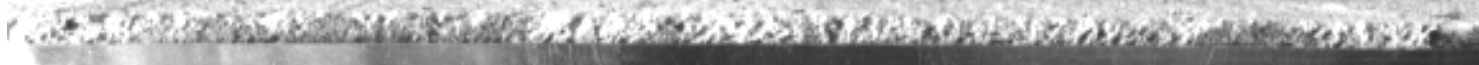

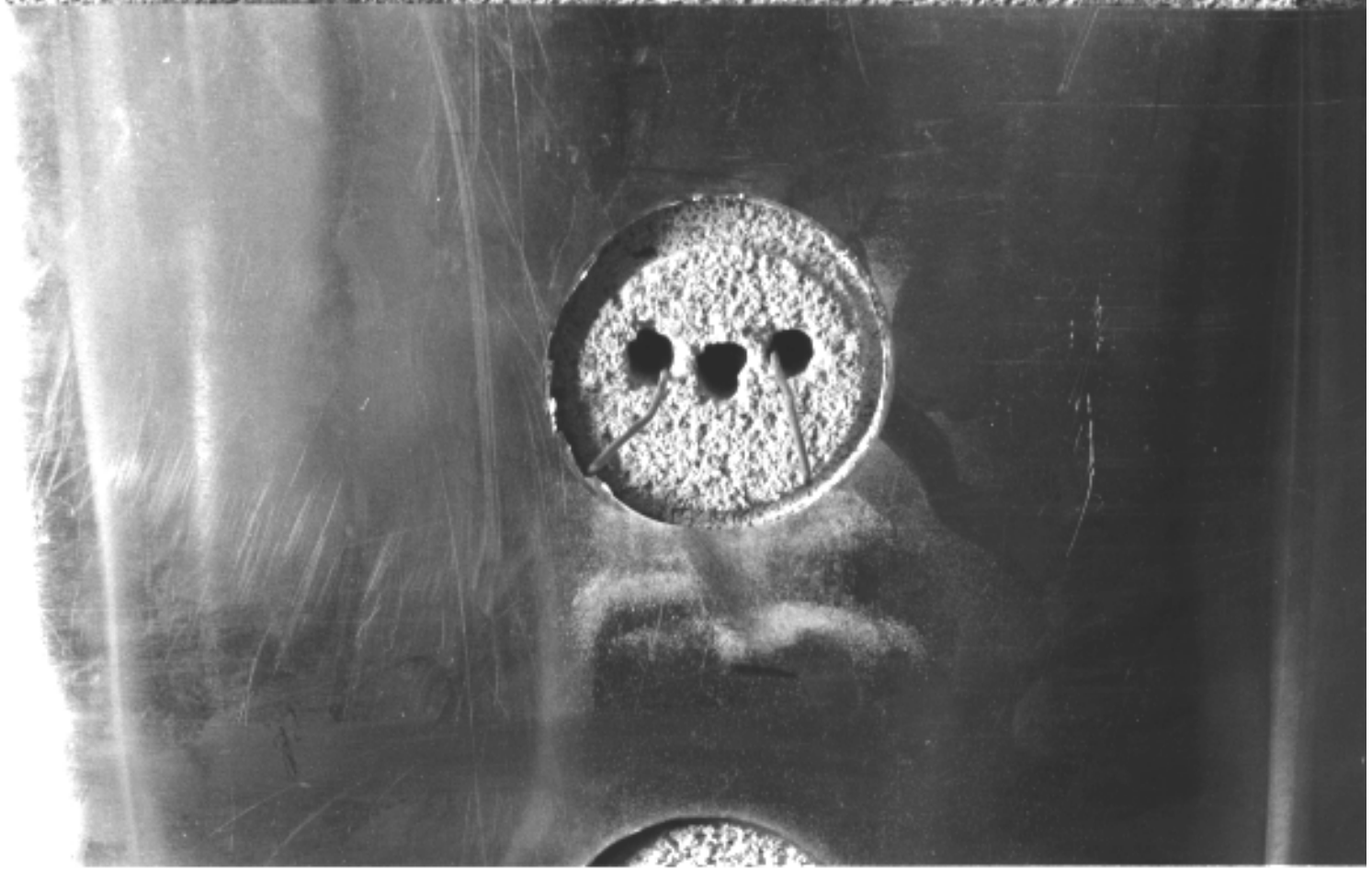




\section{FIGURE 6A}

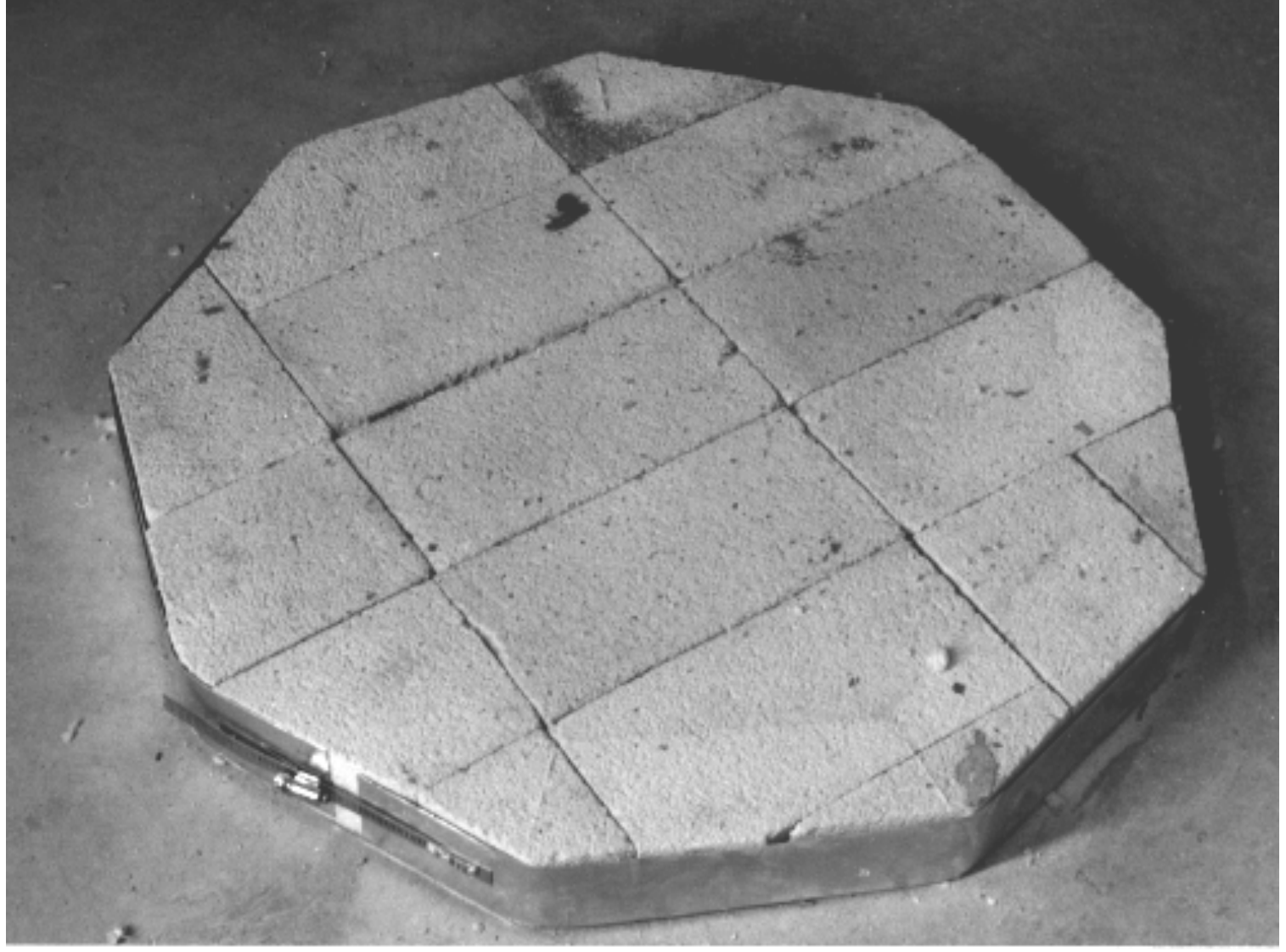

\section{FIGURE 7A}

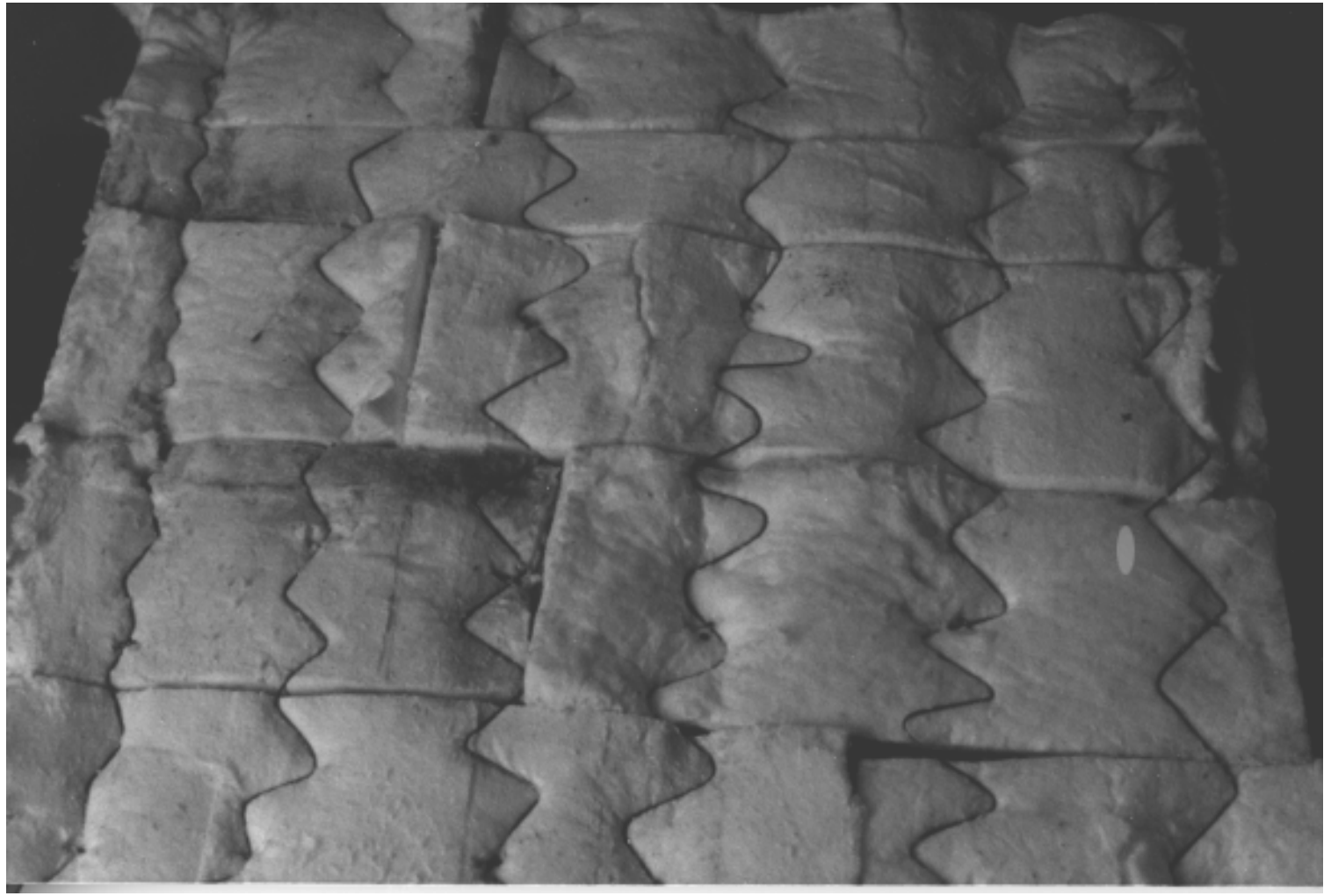




\section{FIGURE 7B}

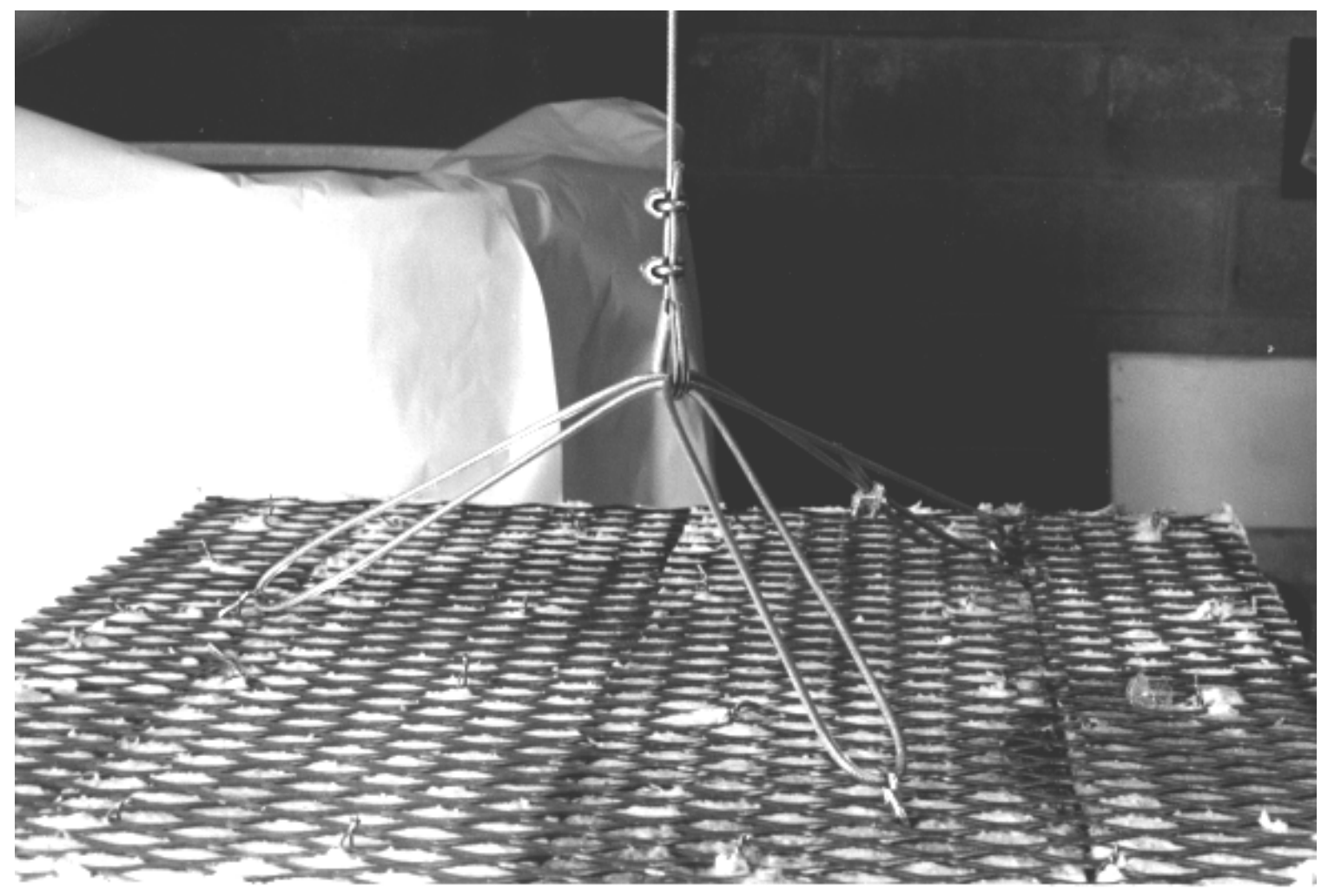

